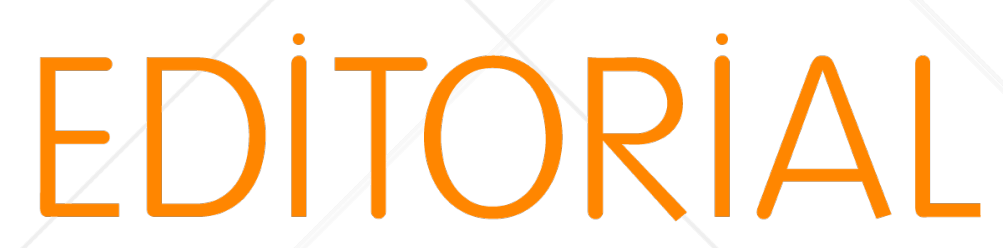

EDITORIAL 


\section{Elogio aos periódicos científicos nas humanidades}

Felizmente já nos acostumamos com a regularidade que a cada quadrimestre um novo número da História da Historiografia é oferecido ao público. Há mais de uma década, teses, dissertações, artigos e a produção científica em geral repercutem o que tem sido publicado nestas páginas. Em bibliografias de cursos de graduação e pósgraduação também encontramos artigos que se tornaram referência essencial no debate de diferentes temas dentro e fora das áreas de especialização do periódico. Embora o grande livro monográfico e autoral continue a ser o ponto culminante da pesquisa em nossas fronteiras, o dia a dia de uma produção científica cada vez mais plural, democrática e diversa acontece nos espaços mantidos pelos periódicos científicos.

Ainda temos dificuldades em lidar com essa nova realidade da produção científica nas humanidades da era digital. Muitos colegas preferem ignorar essa produção científica diversa e dispersa - no sentido de não acontecer mais em torno apenas de grandes centros, autores ou editoras consagradas - e seguem repetindo velhas fórmulas na recusa em responder crítico-criativamente ao novo cenário. Essa resistência explica, apenas em parte, o fato de termos indicadores de citação proporcionalmente muito abaixo do número de acesso e de leitores de nossos periódicos.

No tempo do livro impresso bastava um passeio pelas estantes para reencontrar seus interlocutores e fontes. A existência de uma biblioteca vasta, vaidosa e privada era condição quase incontornável da vida letrada. $\mathrm{Na}$ era do texto digital e da publicação em fluxo, sem o uso de programas e aplicativos, a exemplo do Mendeley, Zotero, Citavi, dentre outros, para organizar a crescente bibliografia e padronizar referências, corremos o risco de produzir um conhecimento empobrecido e provinciano. Para avançarmos 
em uma cultura da citação e do diálogo que dê sentido à crescente e cada vez mais democrática produção bibliográfica, precisamos incorporar de modo crítico e cotidiano as novas ferramentas digitais. Por enquanto, precisamos admitir que citamos pouco e de modo assistemático, levando à perpetuação de nossa situação subalterna, priorizando ainda a tradução e referência a nomes consolidados em sistemas acadêmicos europeus e norte-americanos. Claro que esse cenário pode ser muito diferente nas diversas especialidades que formam hoje uma disciplina nada homogênea.

No último fórum de coordenadores de pós-graduação da Anpuh-Brasil, realizado em novembro em Manaus, foi discutido documento produzido pelo Fórum de Editores acerca do uso de ferramentas bibliométricas como fator complementar na metodologia do Qualis periódico. O conjunto das disciplinas da área de humanidades foi acionado pela Capes para apontar quais ferramentas bibliométricas estariam mais adequadas às suas especificidades. No caso dos periódicos de história, $\mathrm{O}$ fórum de editores indicou $\mathrm{O}$ uso do índice $\mathrm{H}$ produzido a partir da base do Google Acadêmico, não no curto intervalo de 5 anos que o serviço oferece, mas de dez anos, produzido com a ajuda de um programa chamado Publish or Perish. A recomendação do uso desse indicador assinala mudança importante de postura da área, que até então se recusava - não sem boas razões - a adotar metodologias dessa natureza.

O uso de métricas pode contribuir para ampliar o debate em nossa disciplina sobre as formas de avaliar o impacto e a relevância do que é publicado, temperando talvez o viés pela quantidade de produtos que tem sido historicamente induzido pela recepção da avaliação Capes, com um olhar mais atento para a qualidade e o impacto dessa produção. Longe de concluir, essa decisão deve iniciar um amplo debate, com base em estudos mais detalhados sobre as melhores formas de medir a qualidade do que publicamos. 
Quando consideramos tais métricas, a História da Historiografia encontra-se no mesmo patamar das principais revistas nacionais na área de história, o que não deixa de ser extraordinário, considerando seu caráter especializado. Nossa revista tem contado com o apoio entusiasmado de uma comunidade pequena, mas muito atuante e organizada, temos conseguido debater juntos a importância da manutenção deste espaço, o que se prova no apoio financeiro espontâneo que essa comunidade tem nos prestado através de nossos financiamentos coletivos. Infelizmente o cenário brasileiro parece indicar que precisaremos cada vez mais desse esforço.

Um sistema de periódicos independente, academicamente relevante e socialmente enraizado deve estar no centro de nossas preocupações - e alvo das autoridades que temem pela legitimidade de seu poder. Em um tempo de notícias falsas, de ciência falsa, de revisionismos lastreados em falsificações e negacionismos, defender os espaços de debates razoáveis é defender a democracia. Com exceção talvez das teses e dissertações, nem um outro veículo de publicação é tão rigorosamente cuidado e verificado quanto um artigo de periódico. $\mathrm{Na} H H$, até que possa vir a público, qualquer artigo passa por quase duas dezenas de ações cujo único objetivo é verificar e aprimorar a qualidade e integridade do que será publicado. Essa jornada começa por uma primeira triagem na qual se verificam aspectos formais e indícios de eventual plágio; análise preliminar pelos editores executivos; distribuição a pelo menos dois pareceristas em sistema de duplo cego; nova análise dos editores e envio de considerações aos autores; retorno do texto modificado que será novamente conferido por pareceristas e editores; revisão e normalização de notas e referências; atribuição de identidade digital única (DOI); editoração; nova conferência; ajustes; leitura final dos autores e, finalmente, o imprimatur.

É preciso cuidar ainda para que a revista esteja indexada em diversas plataformas que ajudam na divulgação de seu 
conteúdo e na produção de métricas. Quando são repositórios, essas plataformas garantem a integridade e permanência desse conteúdo; afinal, não podemos admitir que esse patrimônio desapareça com a volatilidade do suporte digital. A presença em diversos repositórios é a maior garantia que podemos ter dessa permanência e integridade, mas é uma ação que exige esforço contínuo dos editores e de toda equipe. Não é nossa intenção cansar o leitor com todos esses detalhes, mas em um momento em que a existência dessas revistas é colocada em risco, precisamos ampliar nossa consciência de seu valor insubstituível.

Mas o trabalho editorial não se encerra com a publicação dos artigos a cada número. É preciso fazer esse artigo chegar aos leitores, despertar sua curiosidade e apontar a relevância de cada texto. A exemplo de outros importante periódicos de nossa área, a HH desenvolve ações de divulgação científica e história pública, em especial através do portal HHMagazine humanidades em rede. Neste semestre inauguramos o podcast O que a HH faz?, no qual os autores são convidados a apresentar para um público não especializado as ideias centrais de seus artigos. Entendemos que a função de um periódico científico na área de história não se esgota na comunicação científica, que deve servir de plataforma de mediação entre essa produção e a sociedade, e que, ao lado da relevância científica, a historiografia precisa sempre cuidar de sua relevância social e cultural.

A defesa dos periódicos passa também por uma reflexão mais ampla sobre o lugar que as coletâneas de artigos deveriam ter em nossa matriz de publicações científicas. Em sua maior parte, os processos curatoriais das coletâneas são mais fluidos, há maior risco de endogenia, menor certeza quanto à revisão por pares, ausência de serviços regulares de indexação dos artigos e, consequentemente, menor potencial de impacto e citação das contribuições individuais. Por outro lado, produzir uma coletânea é mais barato e rápido do que editar periódicos. 
Autores já consagrados acabam priorizando a publicação em coletâneas por essas facilidades, mas com isso retiram do sistema de periódicos artigos de maior amadurecimento, os quais poderiam ser ainda mais aprimorados pela cadeia editorial dos bons periódicos. Ao mesmo tempo, poderíamos ter boas coletâneas que funcionassem como manuais ou introduções à literatura especializada, seja reeditando artigos seminais, seja produzindo material coligido para o ensino superior e básico ou mesmo em ações de história pública. As coletâneas poderiam ainda servir aos autores como veículos para reunir sua produção de artigos em periódicos, dando ao conjunto uma unidade difícil de recuperar em seus contextos originais de publicação.

No Edital 2019 do CNPq destinado ao apoio de periódicos nacionais, nem uma das 16 revistas da área de história foi contemplada. Além de nossa $H H$, diversas outras revistas consolidadas e tradicionais não obtiveram financiamento, mesmo que aprovadas pelo mérito de suas solicitações. 0 quadro se explica, em parte, pelo corte brutal no orçamento, reduzido de 4 para 1 milhão entre 2018 e 2019, tendo a Capes se retirado dessa ação. Mesmo assim, a área de história foi estranhamente destacada, gerando razoáveis acusações de discriminação.

Se alguém tinha dúvida sobre nossa relevância social, está aí um bom indicador, a historiografia e os historiadores continuam a parecer perigosos aos donos do poder.

Continuemos assim!

Valdei Araujo

Mariana, 2 de dezembro 2019 